\title{
Notes
}

\section{OMB Intervention in Agency Rulemaking: The Case for Broadened Record Review}

\author{
Steven T. Kargman
}

\section{President Reagan's adoption of Executive Order 12,291' ("E.O.}

1. 3 C.F.R. 127 (1981), reprinted in 5 U.S.C. $\$ 601$ app. at $431-34$ (1982) [hereinafter cited as E.O. 12,291]. E.O. 12,291 establishes a system of pre-clearance review of proposed agency rules conducted by the Office of Management and Budget ("OMB") in accordance with certain economic principles, including cost-benefit analysis. For a fuller discussion of the mechanics of E.O. 12,291, see infra notes 3-4 and accompanying text.

E.O. 12,291 has sparked a considerable debate regarding its constitutionality. Several commentators have argued that E.O. 12,291 may violate separation of powers. See, e.g., M. RosENBERG, PRESIDENtial. Control of Agency Rulemaking: An Analysis of Constitutional Issues That May Be: Raised by Executive Order 12291, Report Prepared by the Cong. Res. Serv. for the House Comm. on Energy and Commerce, 97th Cong., 1st Sess. 46 (Comm. Print 1981) [hereinafter cited as ROSENBfrg, RfPORT]; Olson, The Quiet Shift of Power: Office of Management \& Budget Supervision of Environmental Protection Agency Rulemaking Under Executive Order 12,291, 4 VA. J. NAT. ResouRcrs L. 1, 24-25 (1984). Other commentators, however, have defended the constitutionality of E.O. 12,291 as a proper exercise of presidential coordination of Executive Branch action. See, e.g., Department of Justice, Office of Legal Counsel, Memorandum of February 13, 1981, at 1-3 [hereinafter cited as DOJ Memorandum], reprinted in Role of OMB in Regulation: Hearing Before the Subcomm. on Oversight and Investigations of the House Comm. on Energy and Commerce, 97th Cong., 1st Sess., 486-88 (1981) [hereinafter cited as Hearing on Role of OMB in Regulation]; Shane, Presidential Regulatory Oversight and the Separation of Powers: The Constitutionality of Executive Order No. 12,291, 23 ARIz. L. REv. 1235 (1981); Strauss \& Sunstein, Regulatory Reform: The Presidential Role, ABA AD. L. SEctION (1985).

While the constitutional debate has yet to be resolved, OMB review will, in the meantime, continue to be an institutional feature of the administrative process. Thus, the question for the foreseeable future is how courts should deal with the unique problems posed by OMB involvement in agency decisionmaking. There has been some commentary regarding the implications of E.O. 12,291 for the process of judicial review, which has focused on the issue of whether OMB review interferes with an agency's compliance with its statutory mandate. See, e.g., Silverglade, Judicial Control of Regulatory Action Based on Cost-Benefit Analysis, 36 AD. L. REv. 387 (1984). This Note deals with an issue that has not been considered systematically in the earlier commentary on judicial review: how to ensure effective judicial review of agency action under E.O. 12,291 where the administrative record subject to judicial review may not adequately reflect communications between an agency and OMB. 
12,291") has given the Office of Management and Budget ("OMB") a central role in agency rulemaking. ${ }^{2}$ E.O. 12,291 permits OMB to have wide-ranging influence on rulemakings by executive agencies, ${ }^{3}$ primarily by requiring these agencies to submit proposed and final rulemaking actions to OMB for review prior to their publication. ${ }^{4}$ OMB has, however, exercised its authority in a way that threatens to erode effective judicial review of agency rulemaking. OMB involvement is not typically reflected in an agency's rulemaking record, ${ }^{5}$ thereby potentially frustrating courts in their efforts to conduct meaningful review of agency rulemakings with significant $\mathrm{OMB}$ involvement. This unrecorded involvement of $\mathrm{OMB}$ in agency rulemakings can endanger crucial public policy objectives in administrative law-including reasoned decisionmaking by agencies and ac-

2. Rosenberg argues that E.O. 12,291 "establishes for the first time a centralized mechanism for presidential management of agency rulemaking activities." ROSENBERG REPORT, supra note 1, at 6. Rosenberg contrasts OMB review under E.O. 12,291 with earlier presidential review efforts. Id. at 10-12.

3. Under E.O. 12,291 , if a proposed rule is considered "major," E.O. $12,291 \S 1$ (b), the agency must submit the proposed rule, together with a preliminary Regulatory Impact Analysis, to OMB at least 60 days prior to the publication of a notice of proposed rulemaking in the Federal Register. Id. $\S$ 3(c)(2). Should OMB determine that this regulatory analysis is deficient, it may order a delay in the publication of the notice of proposed rulemaking or of the preliminary Regulatory Impact Analysis until it has submitted its comments to the agency and the agency has responded. Id. $\$ \S 3(\mathbf{f})(1)-(2)$. E.O. 12,291 does not impose any time limits within which OMB must complete its review. Id. § 3(e)(2).

Another recent executive order, Executive Order 12,498 ("E.O. 12,498") requires that the heads of executive agencies subject to E.O. 12,498 "shall ensure that all regulatory actions are consistent with the goals of the agency and of the Administration." E.O. 12,498 § 1(b), 46 Fed. Reg. 1036 (1985), reprinted in 5 U.S.C. $\$ 601$ app. at $40-41$ (Supp. II 1984). E.O. 12,498 thus involves OMB in the rulemaking process at an earlier stage than under E.O. 12,291, since it permits OMB to block regulatory actions contrary to $\mathrm{Administration} \mathrm{policies} \mathrm{before} \mathrm{they} \mathrm{are} \mathrm{even} \mathrm{initiated} \mathrm{by} \mathrm{the} \mathrm{agencies.} \mathrm{Al-}$ though this Note does not specifically analyze the issues involved in the E.O. 12,498 context because the contours of that order have not been as fully developed as those of E.O. 12,291, its analysis can logically be extended to that field.

4. E.O. 12,291 also applies to existing rules. E.O. $12,291 \S 6(\mathrm{a})(1)$. The focus of this Note's analysis, however, is on proposed rules because it is review of new rules influenced by OMB that presents novel questions for judicial review.

5. See, e.g., Staff of House Comm. on Energy and Commerce, Subcomm. on Oversight and Investigations, 99Th Cong., 1st Sess., EPA's Asbestos Regulations: Report on A Case: Study on OMB Interference in Agency Rulemaking 103 (Comm. Print 1985) (reporting extensive pattern of undocketed communications between industry representatives and OMB as well as between OMB and Environmental Protection Agency (EPA) in asbestos rulemaking) (hereinafter cited as Asbrstos Report]; see also Staff of House Comm. ON ENERGY and Commerce,

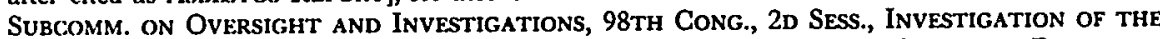
Environmental. Protection Agency: Report on the President's Claim of Executive Privil.f.(se over EPA Documents, Abuses in the Superfund Program, and Other Matters 293 (Comm. Print 1984) (discussing oral rather than written directives from OMB to EPA, failure to record OMB input in EPA rulemaking docket, secret meetings between OMB and industry representatives, and unrecorded meetings between OMB and EPA) [hereinafter cited as INVESTIGATION OF EPA]; Gentral. Accounting Office, ImProved Qualtry, AdeQuate Resources, and Consisten'l Oversigh'r Nefded If Regulatory Analysis Is To Hetp Control Costs of RegulaTIONS 53 (Nov. 2, 1982) (arguing that "[n]ot only does OMB generally communicate with agencies orally rather than in writing, but in at least one case, OMB resisted putting its opinions on paper even when the agency asked it to do so"). 
cess to the rulemaking process by all parties-which effective judicial review safeguards.

To ensure meaningful judicial review in the face of OMB involvement, this Note proposes that the courts broaden the administrative record subject to judicial review. Under this approach, the courts should undertake broadened record review where it can be established that OMB significantly altered the course of a rulemaking. In such cases, reviewing courts should have access to all documents relating to communications between OMB and the agency. The approach of this Note will allow careful scrutiny by the courts of the real basis for an agency's decision in OMBinfluenced rulemakings, and will ensure reasoned, expert decisionmaking with full public participation.

Part I of this Note demonstrates the problems OMB intervention in agency rulemaking creates for the process of judicial review. Part II argues that the proper judicial characterization of OMB involvement in the administrative process can lead to a solution to the judicial review problem. Part III concludes with a proposed solution whereby courts undertake broadened record review of OMB-agency communications.

\section{OMB Intervention in Agency Rulemaking and the Problems for Judicial Review}

\section{A. The OMB Review Process and the Principle of Review on the Record}

The stated purpose of E.O. 12,291 is to implement principles such as cost-benefit analysis. ${ }^{6}$ Since the adoption of E.O. 12,291, OMB has exercised its authority broadly in several major rulemakings: OMB has forced $^{7}$ agencies to withdraw proposed rules, ${ }^{8}$ substantially delayed the

6. Among other objectives, regulations reviewed by OMB pursuant to E.O. 12,291 must be based on adequate information, the benefits to society must outweigh the potential costs to society, and the regulatory alternative involving the least net cost to society must be chosen. E.O. $12,291 \S 2$.

For contrasting views on the policy dimensions of OMB review, see DeMuth \& Ginsburg, White House Review of Agency Rulemaking, 99 HARv. L. REv. 1075 (1986) (arguing necessity of regulatory planning and review by Executive Office of President in modern regulatory state); Morrison, OMB Interference with Agency Rulemaking: The Wrong Way To Write a Regulation, 99 HARv. L. REv. 1059 (1986) (arguing that OMB review operates in manner inconsistent with basic principles underlying informal rulemaking). For a compilation of comprehensive Congressional Research Service studies on the development of the key institutional roles of OMB, see OFFICE OF MANAGEMENT AND Budget: Evolving Roles and FutruRe Issues, Report Prepared by the Cong. Res. Serv. for the Senate Comm. on Governmental Affairs (with an Overview Prepared by the Comm. Staff), 99th Cong., 2d Sess., S. Rep. No. 134 (1986) [hercinafter cited as OMB's Evolving Roles].

7. While in theory OMB is not authorized even under the terms of E.O. 12,291 to require an agency to comply with its views, E.O. 12,291 \$ $3(\mathrm{f})(3)$, in practice OMB may have decisive influence on certain agency rulemakings. As the current Director of OMB, James Miller, once explained: "If you're the toughest kid on the block, most kids won't pick a fight with you. The executive order establishes things quite clearly." Deregulation HQ REgulation, Mar.-Apr. 1981, at 14, 19. For a fuller discussion of the reasons why OMB influence may be determinative of an agency outcome, see infra notes 68-70 and accompanying text.

8. See EPA's Asbestos Regulations, Hearing Before the Subcomm. on Oversight and Investiga- 
publication of proposed rules, ${ }^{9}$ and weakened rules on the basis of costbenefit criteria that, in certain instances, were precluded from agency consideration by statute. ${ }^{10}$

Nevertheless, OMB has made itself unaccountable for its influence on the administrative process by withholding its communications from an agency's rulemaking record, and by generally keeping its involvement secret. ${ }^{11}$ During the course of a rulemaking, OMB officials may engage in numerous telephone calls and meetings with agency officials, and yet public disclosure of these communications may be virtually non-existent. In addition, OMB staff may receive secret communications from private parties regarding a rulemaking.

Under traditional judicial review doctrine, if a rulemaking is challenged in court by an aggrieved party, the scope of review is limited to a "review on the record;" that is, a court generally will not undertake de novo review, but will confine its review to the administrative record on which the

tions of the House Comm. on Energy and Commerce, 99th Cong., 1st Sess. (1985) (OMB forced EPA to withdraw proposed rules concerning banning and phasedown of various asbestos uses) (hereinafter cited as Hearing on Asbestos]; INvestigation of EPA, supra note 5, at 285 (OMB forced EPA to eliminate proposed rule dealing with degradation of water quality under Clean Water Act).

9. See Environmental Defense Fund v. Thomas, No. 85-1747 (D.D.C. Jan. 23, 1986) (EPA notice of proposed rulemaking for final permitting standards for underground hazardous waste tanks impermissibly delayed by OMB beyond statutory deadline).

10. See Office of Management and Budget Control of OSHA Rulemaking, Hearings Before the Subcomm. on Manpower and Housing of the House Comm. on Government Operations, 97th Cong., 2d Sess. 357 (1982) (OMB forced Occupational Safety and Health Administration (OSHA) to delay and weaken proposed hazard communication rule on basis of cost-benefit criteria that were precluded from agency consideration by statute); EPA: Investigation of Superfund and Agency Abuses (Part 3), Hearings Before the Subcomm. on Oversight and Investigations of the House Comm. on Energy and Commerce, 98th Cong., 1st Sess. 81 (1983) (OMB forced EPA to subject health-based Clean Air Act standards to cost-benefit considerations that Congress determined should not apply) (hereinafter cited as Hearings on Superfund].

11. See, e.g., ASBESTOS REPORT, supra note 5, at 100-08 (arguing that Congress' intention to provide for meaningful public participation in EPA rulemakings has been nullified by OMB's secret, off-the-record communications with agencies and private parties). OMB has apparently made an effort not to leave any paper trail of its involvement in the administrative process. An important part of this strategy is to deliver orally any comments on agency rules and thus not "leave fingerprints" in the administrative record. See Washington Post, July 10, 1981, at A21, col. 2 (quoting Jim Tozzi, Deputy Director, Office of Information and Regulatory Affairs, OMB). For a case study of how OMB prefers to operate in secrecy, see Hearing on the Oversight of the Office of Management and Budget Regulatory Review and Planning Process Before the Subcomm. on Intergovernmental Relations of the Senate Comm. on Governmental Affairs, 99th Cong., 2d Sess. (1986) (forthcoming) (statement of Deborah Berkowitz, Director, Safety and Health, Food and Allied Services Trade Dept., AFL-CIO) (discussing instance where OSHA wished to present 27 page written rebuttal to OMB comments, instead orally transmitted information to OMB at OMB's insistence) (hereinafter cited as Hearing on Oversight of OMB Regulatory Review Process]. See generally Olson, supra note 1, at 59-60 (arguing that due to undocumented OMB contacts with agency, "it [is] almost impossible for the public or reviewing court to know the extent of OMB involvement in any given rulemaking, or in EPA rulemaking as a whole").

Agencies, of course, remain free to docket and summarize contacts with OMB. Nevertheless, as a general matter, OMB has "vehemently opposed any effort to require it (or an agency) to log, summarize or docket the Office's oral contacts with the agency or outside parties." Id. at 59. 
decision was made. ${ }^{12}$ Two major Supreme Court cases, Citizens to Preserve Overton Park $v$. Volpe $e^{13}$ and Camp v. Pitts, ${ }^{14}$ reaffirmed the traditional narrow definition of what constitutes the judicially-reviewable agency record. In these two cases, the Court stated that judicial review should be based on the existing administrative record, not a new record compiled in the reviewing court. ${ }^{15}$

Review on the record may be severely hampered where there has been significant undocumented OMB involvement in an agency rulemaking because this involvement generates two different 'records': one reflecting what happened during the agency's public rulemaking proceedings, and the other reflecting what happened between the agency and OMB. ${ }^{16}$ In the past-when there was no OMB involvement-only the former record existed, and this record included the agency's findings as well as documents evidencing public participation in the rulemaking. ${ }^{17}$ This package was submitted by the agency for judicial review when agency action was challenged in court. ${ }^{18}$ If review on the record is applied where there is active OMB involvement in a rulemaking, a court will see only the first record, reflecting what happened during the agency's public proceedings. ${ }^{19}$ A court will not, however, see any documents reflecting what happened between the agency and OMB because these communications are not included in the administrative record. In short, application of "review on the record" may result in courts reviewing a woefully incomplete administrative record.

12. See, e.g., McMillan \& Peterson, The Permissible Scope of Hearings, Discovery, and Additional Fact $\Delta$ Finding During Judicial Review of Informal Agency Action, 1982 Duke L.J. 333, 338 (informal agency action is subject to judicial review, but with strict limitations on such review); Stark \& Wald, Setting No Records: The Failed Attempts to Limit the Record in Review of Administrative Action, 36 AD. L. REv. 333, 334 (1984) (courts circumscribe inquiry to what they commonly describe as "review on the record").

13. 401 U.S. 402 (1971).

14. 411 U.S. 138 (1973).

15. In Overton Park, the Court instructed the district court on remand to conduct its review "based on the full administrative record that was before the Secretary at the time he made his decision." 401 U.S. at 420 . In Camp, the Court reaffirmed the Overton Park conclusion that review should be conducted on the basis of the "administrative record already in existence." Camp, 411 U.S. at 142 .

16. See, e.g., Brief of Representatives John D. Dingell, Peter W. Rodino, Jr., Jack Brooks, Augustus Hawkins, and William D. Ford, as Amici Curiae in Support of Petitioners, Public Citizen Health Research Group v. Rowland, Nos. 84-1252, 84-1392, and 85-1014 (D.C. Cir. brief filed June $28,1985) 25$ (arguing that by shifting locus of decisionmaking from agency that keeps record to which public can respond and courts can review to agency that does not (i.e., OMB), OMB has effectively undermined Congress' intentions regarding nature of rulemaking process).

17. See Administrative Procedure Act (APA), 5 U.S.C. $\$ 553$ (1982) (notice-and-comment provisions for informal rulemaking).

18. The $\Lambda P \Lambda$ states that "the court shall review the whole record or those parts of it cited by a party." 5 U.S.C. $§ 706$ (1982).

19. See, e.g., AsBestos REPORT, supra note 5, at 108 (arguing that neither Congress nor courts should continue to treat agency's administrative record as if it were real basis for rulemaking decisions when it has been subject to OMB review). 


\section{B. Secret OMB-Agency Communications and their Significance for Ju- dicial Review}

If courts are to avoid reviewing an incomplete and possibly misleading record, they need to understand the anatomy of OMB-influenced rulemakings as involving three sets of interactions between the agency and OMB. The first set of interactions relates to the flow of communications from the agency to $\mathrm{OMB}$ with respect to a proposed rule. The second set of interactions covers $\mathrm{OMB}$ communications to the agency. The third set of interactions concerns $\mathrm{OMB}$ contacts with outside parties during rule review, with OMB possibly serving as a conduit for these parties in dealing with the agency. Each of these three sets of interactions has important, distinct consequences for judicial review and the appropriate scope of the record.

\section{Interaction I: Agency Communications to OMB}

Agency communications to OMB can occur both before and after an agency has submitted a proposed or final rule to OMB for review. These communications to $\mathrm{OMB}$ can reveal how the agency would have acted in a given rulemaking if the agency alone were promulgating the rule. ${ }^{20}$ The reason courts should focus on these communications relates to the traditional judicial concern with "danger signals" in agency rulemakings, which courts define as abrupt shifts in agency policy. ${ }^{21}$ These danger signals may indicate that the agency is acting in an arbitrary manner.

Courts should also attempt to isolate this interaction because without

20. See, e.g., Petitioners' Brief in Public Citizen Health Research Group v. Rowland, Nos. 841252, 84-1392, and 85-1014 (D.C. Cir. brief filed March 4, 1985) [hereinafter cited as Public Citizen Petitioners' Brief]. The Public Citizen case involves the deletion of a short-term exposure limit ("STEL") from a health standard established by OSHA for the substance ethylene oxide ("E1O"). Petitioners challenged this deletion of a STEL by OSHA and alleged that the deletion had been prompted unlawfully by the influence of OMB. Petitioners argued that OSHA had originally favored a STEL, and following months of informal notice-and-comment rulemaking, had transmitted to OMB an EtO standard that included a STEL. In short, petitioners alleged that OSHA would have adopted a STEL but for OMB intervention.

21. See, e.g., Greater Boston Television Corp. v. FCC, 444 F.2d 841, 852 (D.C. Cir. 1970) (judicial vigilance demanded where agency policies are in flux), cert. denied, 403 U.S. 923 (1971); Baton Rouge Marine Contractors v. Federal Maritime Comm'n, 655 F.2d 1210, 1215 (D.C. Cir. 1981) (close scrutiny appropriate in light of agency's departure from previously stated position); see also Garland, Deregulation and Judicial Review, 98 HARv. L. REv. 505, 517-20 (1985) (applying "danger signals" analysis to deregulation cases). For a fuller discussion and application of danger signals, see infra notes 84-85 and accompanying text.

In the OMB context, danger signals might arise under the following circumstances. An agency plans to promulgate Rule A and instead adopts Rule B. However, it adopts Rule B where this rule is not supported by the record comments of anyone else or by some new data concerning the rulemaking. Danger signals are therefore trigged by the question: Where did Rule B come from? A party seeking to demonstrate danger signals would do so by introducing some evidence of crucial OMB involvement in the rulemaking which might help explain the otherwise inexplicable agency departure from Rule A to Rule B. 
OMB involvement the judiciary may be more willing to defer to a tentative administrative decision. Where an agency has settled on its course of action without OMB involvement, courts could rely on presumptions of agency expertise, ${ }^{22}$ the procedural regularity of the administrative process, ${ }^{23}$ and full public discussion and participation in the rulemaking. ${ }^{24}$

\section{Interaction II: OMB Communications to the Agency}

OMB communications to the agency represent the crux of the E.O. 12,291 process because they relate to OMB review of proposed rulemakings. While virtually none of these communications will be found in the administrative record, some of these communications may be formal and contained in memoranda and other written documents. ${ }^{25}$ Given OMB's preference for secrecy, the majority of these communications may be informal and conducted over the telephone on a regular basis; yet documentation of these communications may well exist. ${ }^{23}$

The courts will want to consider this interaction for several reasons. First, this interaction may indicate the factors that OMB brought to bear on the rule ultimately adopted by the agency. The courts can compare these factors with the statutorily-mandated factors to determine whether the ultimate agency rule survives the "arbitrary and capricious" standard of review. ${ }^{27}$ Second, because OMB wields substantial political clout

22. See, e.g., B. Ackerman \& W. Hassler, Clean Coal/Dirty Air (1981) (describing New Deal ideal affirming agency expertise).

23. See Overton Park, 401 U.S. at 415 (Secretary's decision entitled to presumption of regularity).

24. See, e.g., Stewart, The Reformation of American Administrative Law, 88 HARV. L. REv. 1667 (1975) (describing ways in which agency rulemaking has become increasingly characterized by public participation); Gellhorn, Public Participation and Administrative Proceedings, 81 YALE L.J. 359 (1972) (same).

25. These communications may be reflected in OMB briefing books on an agency rulemaking, see Hearing on Asbestos, supra note 8, at 128-33 (containing EPA official's handwritten notes of cover memorandum summarizing OMB Director David Stockman's briefing book on asbestos as well as OMB legal memorandum in briefing book), or in formal correspondence or memoranda from OMB to the agency, see id. at 246-52 (letter from top OMB official to Acting Deputy Adm'r of EPA outlining "flaws" in withdrawn EPA draft proposals).

26. Such communications may be reflected in notes by agency officials on OMB telephone calls, see id. at 125 (typewritten agency notes expressing OMB concern that proposed EPA phasedown rule on asbestos not cost-effective). For an interesting chronology of events in an OMB-influenced rulemaking detailing the points of contact and the nature of communications between the agency and $\mathrm{OMB}$, see id. at 21-33.

27. See, e.g., Overton Park, 401 U.S. at 411-13 (where statute indicated that protection of parkland was to be given paramount importance in highway construction, Secretary of Transportation was prohibited from balancing benefit of parkland preservation against cost and other factors unless Secretary finds that alternative non-parkland routes "present unique problems"); see also American Textile Mfr's Inst. v. Donovan, 452 U.S. 490, 509 (1981) (Congress defined basic relationship between costs and benefits by placing benefit of worker health above all other considerations except those making attainment of this benefit unachievable).

If OMB's analysis was impermissible under the statutory scheme and was determinative of the agency outcome, then a court would have grounds for invalidating the agency action as "arbitrary and capricious." 
within the Executive Branch, it may attempt to exert raw influence that is plainly unlawful ${ }^{28}$ and similar in some respects to that which has been prohibited in the congressional-agency context. ${ }^{28}$

\section{Interaction III: OMB Conduit Contacts to the Agency}

Private party communications to $\mathrm{OMB}$, where $\mathrm{OMB}$ serves as a conduit to the agency for these communications, may be viewed as ex parte contacts between these parties and the agency. ${ }^{30}$ When OMB acts as a conduit to the agency for these ex parte contacts, the ultimate rule issued by the agency may therefore be influenced by these contacts. OMB may in some cases mask from the agency the private origins of a rule change. ${ }^{31}$ Outside parties may believe that it is more efficacious to have reinforcement from OMB in the form of these indirect conduit contacts rather than restating their views to the agency.

\section{Public Policy Objectives Endangered by Frustrated Judicial Review}

Effective judicial review of agency rulemaking protects two central public policy objectives in administrative law: reasoned decisionmaking by agencies and access by all parties to the rulemaking process. By frustrating meaningful judicial review, undocumented OMB involvement in the administrative process endangers these public policy objectives.

28. See, e.g., Investigation of EPA, supra note 5, at 287 (Daniel testimony) (former EPA chief of staff testifying regarding threatening telephone call from high-ranking $O M B$ official in case where EPA issued regulations over OMB's objections: "But he said to me words to this effect that there was a price to pay for doing what we had done, and that we hadn't begun to pay.").

29. See, e.g., Pillsbury Co. v. FTC, 354 F.2d 952 (5th Cir. 1966) (commission order vacated where thrust of senators' comments and questions at Senate subcommittee hearings was directed to correctness of commission's approach in specific case); District of Columbia Fed'n of Civic Ass'ns v. Volpe, 459 F.2d 1231, 1245 (D.C. Cir. 1971) ("the defects in the Secretary's determinations . . . lend color to plaintiff's contention that the repeated and public threats by a few Congressional voices did have an impact on the Secretary's decisions"), cert. denied, 405 U.S. 1030 (1972).

Executive policy guidance may be permissible, see Sierra Club v. Costle, 657 F.2d 298, 408 (D.C. Cir. 1981), and thus distinguishable from congressional intermeddling in agency rulemaking. Raw political influence exercised by $\mathrm{OMB}$ is, however, a different matter from Executive policy guidance and more analogous to the proscribed congressional influence discussed above.

30. Some courts have restricted ex parte contacts, particularly in proceedings rather like formal adjucications. See, e.g., Home Box Office, Inc. v. FCC, 567 F.2d 9, 56-59 (D.C. Cir.) (requiring disclosure of ex parte contacts because ex parte contacts with agency engaged in rulemaking violates fundamental notions of fairness implicit in due process) cert. denied, 434 U.S. 829 (1977). But see Action for Children's Television v. FGC, 564 F.2d 458, 477 (D.C. Cir. 1977) (ex parte contacts restrictions limited to cases where there are "competing claims to a valuable privilege").

In E.O. 12,291 rulemakings, courts should be especially sensitive to ex parte contacts because E.O. 12,291 creates a new point of access to the agency rulemaking process, namely, OMB. See RosENBERG; REPORT, supra note 1 , at 62 .

31. For a possible example of such indirect conduit contacts, see Public Citizen Petitioners' Brief, supra note 20, at 54 (arguing that major segments of OMB's letter opposing standard "plainly are distillations of the comments filed by the key industry opponents to the STEL"). 


\section{Reasoned Decisionmaking}

Reasoned decisionmaking is a major public policy goal because the administrative process exists as a means of generating prudent public policy choices for the government. ${ }^{32}$ In the current era of administrative law, the notion of reasoned decisionmaking can best be understood as the converse of "arbitrary and capricious" decisionmaking. ${ }^{33}$ The Supreme Court has defined the "arbitrary and capricious" standard to include agency consideration of factors not intended by Congress, failure to examine an important aspect of a problem, an explanation unsupported by the record, or an implausible outcome. ${ }^{34}$

Where there is undocumented OMB involvement in the administrative process, courts may be frustrated in their efforts to invalidate such "arbitrary and capricious" decisionmaking. The record for the public and the courts might be that of the agency, but the record on which the decision was made could be largely the secret record of OMB. If a court conducts review on the record, it may be mistakenly reviewing the agency's administrative record as if that were the actual basis for the challenged rulemaking. The agency may seek to justify its action on the basis of the public record, which may disguise the real reasons behind the decision. ${ }^{35}$

\section{Public Participation}

Public participation in the administrative process serves important goals. First, it brings a broader range of views and experience to a problem, thus enabling an agency to formulate a solution based upon better information. ${ }^{36}$ Second, public participation ensures that the agency en-

32. The expertise of agencies is considered a major resource of the government for dealing with complex decisions; the insistence by courts on reasoned decisionmaking ensures that this expertise will be exercised. The requirement of reasoned decisionmaking traces its roots to the drafting of the APA itself, where the emphasis was on giving agencies flexibility and autonomy in formulating policy. See ROSENBE:RG REPORT, supra note 1 , at 46-50.

33. For an early statement of this view, see Automotive Parts \& Accessories Ass'n v. Boyd, 407 F.2d 330, 338 (D.C. Cir. 1968) ("The paramount objective is to see whether the agency, given an essentially legislative task to perform, has carried it out in a manner calculated to negate the dangers of arbitrariness and irrationality in the formulation of rules for general application in the future.").

34. See Motor Vehicle Mfr's Ass'n v. State Farm Mut. Auto. Ins. Co., 463 U.S. 29, 43 (I983).

35. Ordinarily, courts avoid inspecting the "real reason" for an agency action given the prohibition against "probing the mind" of the decisionmaker established in the Morgan doctrine, see infra note 57 , and the disinclination to pursue a generalized inquiry into motive. Consequently, the courts limit themselves to "review on the record." See supra text accompanying notes 12-15. Nonetheless, under certain circumstances, the courts will allow in extra-record evidence. See infra text accompanying notes 77-81. This Note argues that the circumstances permitting the admission of extra-record evidence may be implicated in the OMB context, and thus the courts would have grounds for investigating the "real reason" for agency action.

36. See U.S. Attorney General's Committee on Administrative Procedure, Final Report of Aitrorney General.'s Committee on Administrative Procedure 102 (1941) (agency knowledge is rarely complete, and agency must always "learn the frequently clashing viewpoints of those whom its regulations will affect") (hereinafter cited as ATTORNEY GENERAL's REPORT]. 
gages in a dialogue with the public, ${ }^{37}$ this gives the administrative process a certain legitimacy in the eyes of those who will be affected by agency regulations.

The drafters of the Administrative Procedure Act ("APA") recognized the importance of public participation in the rulemaking process. ${ }^{38}$ The APA mechanism for ensuring public participation consist of the so-called notice-and-comment rulemaking procedures that provide the public with the opportunity to respond to agency proposals. ${ }^{39}$ These notice-andcomment procedures have taken on increased significance in recent years as the courts and Congress have ushered in an interest representation model of rulemaking in which public participation is the linchpin. ${ }^{40}$ Under this model, the agency is viewed as a quasi-legislature whose regulators must weigh and accommodate the "competing claims of various private interests affected by agency policy." "41

Limited judicial review of E.O. 12,291 rulemakings severely undercuts this interest representation model of agency decisionmaking and subverts public participation. Existing inequalities in resources and political power in the rulemaking process may be exacerbated further where OMB has a privileged point of entry for affecting agency decisionmaking. ${ }^{2}$ Given that OMB's review may be decisive to an agency's final course of action, OMB's secret participation could undermine confidence in the openness and fairness ${ }^{43}$ of the rulemaking process.

At the same time that the courts have protected public participation, some courts have also expressed concern over ex parte contacts that undermine public participation. ${ }^{44}$ These courts have considered ex parte con-

37. See, e.g., Wright, The Courts and the Rulemaking Process: The Limits of Judicial Review, 59 Cornel.l. L. REv. 375, 381 (1974) ("Section 553 [of the APA] contemplates that rules will be made through a genuine dialogue between agency experts and concerned members of the public . . . the reviewing court must satisfy itself that the requisite dialogue occurred and that it was not a sham.").

38. See generally ArTORNEY General's RePORT, supra note 36, at 102 (agency procedures should be "adapted to giving adequate opportunity to all persons affected to present their views, the facts within their knowledge, and the dangers and benefits of alternative courses").

39. See 5 U.S.C. $\$ 553$ (1982).

40. See, e.g., Stewart, supra note 24 (discussing changes in judicial doctrine); Gellhorn, supra note 24 (same). Certain "hybrid rulemaking" statutes have also enhanced public participation by combining informal rulemaking procedures with formal adjudication procedures. See, e.g., Toxic Substances Control Act of 1976, 15 U.S.C. $\$ 2605$ (c)(3) (1982) (providing for possibility of rebuttal submissions and cross-examination where administrator determines there are disputed issues of material fact).

41. See Stewart, supra note 24 , at 1683.

42. See AsBestos REPORT, supra note 5, at 98 ("While Congress envisioned equal access to the rulemaking process by all affected parties, OMB has gained a preferred and early vantage point to assert its views.").

43. These are goals embodied generally in the Government in the Sunshine Act of 1976, 5 U.S.C. $\S 552 \mathrm{~b}$ (1982). For a discussion of the Act, see Thomas, The Courts and the Implementation of the Government in the Sunshine Act, 37 AD. L. REv. 259 (1985).

44. See supra note 30 . 
tacts a danger to a variety of policy objectives: ensuring interested parties equal access to the decisionmaker, ${ }^{45}$ protecting the opportunity of outside parties to comment on issues before the agency, ${ }^{46}$ and preserving the meaningfulness of judicial review. ${ }^{47}$

The threat posed by ex parte contacts is substantial in E.O. 12,291 rulemakings, and the same policy concerns underlying some of the ex parte contacts case law is reinforced in these rulemakings. OMB's decisionmaking process is governed neither by a statute prescribing rulemaking procedures nor by the informal rulemaking requirements of the APA. ${ }^{48}$ Moreover, ex parte contacts are no longer an ad hoc matter but rather an institutional feature of E.O. 12,291 rulemakings. ${ }^{49}$

In view of the problems that undocumented OMB involvement presents for judicial review and ultimately for the administrative process itself, the courts must develop an appropriate response. The first step that the courts must take is to reach the proper characterization of OMB involvement in the administrative process.

\section{Proper Judicial Gharacterization of OMB Involvement: Towards a Solution to the Judicial Review Problem}

The way courts characterize OMB involvement in agency decisionmaking has major implications for the appropriate scope of judicial review. There are essentially three models that can be applied: OMB as presidential agent, $\mathrm{OMB}$ as Executive Branch party to an agency rulemaking, or $\mathrm{OMB}$ as decisionmaking authority. For the reasons discussed below, the most accurate way to characterize OMB involvement is as a hybrid of Executive Branch party/decisionmaker. Under this hybrid model, a re-

45. See, e.g., United States Lines v. Federal Maritime Comm'n, 584 F.2d 519, 539 (D.C. Cir. 1978) ("The inconsistency of secret ex parte contacts with the notion of a fair hearing and with the principles of fairness implicit in due process has long been recognized.").

46. See, e.g., Home Box Office, Inc. v. FCC, 567 F.2d 9, 55 (D.C. Cir.) ("we see no difference between assertions of facts and expert opinion tendered by the public . . . and that generated internally in an agency: each may be biased, inaccurate, or incomplete-failings which adversary comment may illuminate"), cert. denied, 434 U.S. 829 (1977).

47.

$\Lambda$ a practical matter, Overton Park's mandate means that the public record must reflect what representations were made to an agency so that relevant information supporting or refuting those representations may be brought to the attention of the reviewing courts by persons participating in agency proceedings. This course is obviously foreclosed if communications are made to the agency in secret and the agency itself does not disclose the information presented. Id. at 54. See also United States Lines, 584 F.2d at 542 (adversarial comment "serves not only to clarify the issues and positions being considered at the agency level, but also to ensure that factual questions underlying the agency's decision are not raised, by necessity, for the first time on judicia! review").

48. See AsBestos REPORT, supra note 5, at 102.

49. See, e.g., Olson, supra note 1, at 56-57 (indicating that OMB encourages ex parte contacts by sometimes actively soliciting industry comments on specific rules but OMB "does not record or summarize these meetings with outside parties"). 
viewing court could review the three sets of interactions between the agency and OMB outlined above. ${ }^{\mathrm{BO}}$

\section{A. OMB as Presidential Agent}

The model of OMB as presidential agent is the one favored by $O M B$ and the Reagan Administration generally. ${ }^{51}$ This model allows OMB to intervene in the E.O. 12,291 rulemaking process just as OMB goes about its other business. ${ }^{52}$ According to this view, OMB is merely playing an advisory role vis-a-vis the agency. ${ }^{63}$

The Reagan Department of Justice has taken the position that communications between $\mathrm{OMB}$ and the agency are covered by the so-called deliberative process privilege against disclosure and are therefore not reviewable by a court. ${ }^{54}$ The Department of Justice grounds this exception to disclosure in the President's constitutional power to "take Care that the laws be faithfully executed," munications within the Executive Branch, ${ }^{56}$ and the prohibition against

50. See supra text accompanying notes $20-31$.

51. See, e.g., DOJ Memorandum, supra note 1, at 3, reprinted in Hearing on Rale of OMB in Regulation, supra note 1, at 488 (E.O. 12,291 fulfills President's constitutional responsibility to "take Care that the Laws be faithfully executed" by promoting coordinated system of regulation); Department of Justice, Office of Legal Counsel, Memorandum to Honorable David Stockman, Director of OMB, Re: Contacts Between OMB and Executive Branch Agencies Pursuant to Executive Order 12291, $\Lambda$ pr. 24, 1981, at 2 (on file with author) (no legal duties on Director or staff of OMB to refrain from communicating with rulemaking agencies) [hereinafter cited as DOJ Memorandum on OMB Contacts]; cf. Strauss \& Sunstein, supra note 1, at 11-12 (Constitutional framers' choice of unitary executive justifies greater presidential control over rulemaking activities of federal agencies).

52. Among its myriad powers and responsibilities, see Olson, supra note 1 , at 7 n.12, OMB reviews agency budgets, see id. at 6 , and sets agency personnel ceilings, see OMB, MEMORANDUM TO Heads of Executive Departments and Establishments: Position Management Systems ANd Empioymant Ceillings (OMB Circular A-64 (Revised)) (July 30, 1980).

53. See, e.g., DOJ Memorandum, supra note 1, at 4-5, reprinted in Hearing on Role of OMB in Regulation, supra note 1, at 489-90 (President may consult with those having statutory decisionmaking responsibilities, as long as President does not divest administrative officer of ultimate statutory authority); E.O. $12,291 \S 3(\mathrm{f})(3)$ ("Nothing in this subsection shall be construed as displacing the agencies' responsibilities delegated by law.").

54. The Department of Justice argues that OMB participates in the deliberative process "when it exercises the power of the President delegated [to OMB] to 'supervise and guide' the agency by communicating factual analyses or legal and policy arguments." See DOJ Memorandum on OMB Contacts, supra note 51 , at 8 .

55. See U.S. Consr. art. II, § 3. Rosenberg disputes the view that Article II grants a general management power to the President to control the administrative decisionmaking process. See ROSENBERG REPOR'T, supra note 1, at 30-34; see also AsBestos REPORT, supra note 5, at 122 (Article II vesting of executive power in President locates situs of power but does not define its content).

56. The Department of Justice cites United States v. Nixon, 418 U.S. 683 (1974), for the proposition that there is a constitutionally-basedprivilege for certain Executive Branch communications. See DOJ Memorandum on OMB Contacts, supra note 51, at 7 . Whether OMB communications with an agency would be protected by executive privilege is unclear. Nixon established two central propositions with respect to executive privilege, neither of which clearly favors an OMB claim to executive privilege. First, Nixon held that executive privilege is not a blanket protection of all communications within the Executive Branch and instead pertains to communications between the President and close advisers. 418 U.S. at 708 . Rosenberg has questioned whether confidentiality under the 
probing the mind of the decisionmaker. ${ }^{57}$ The Department of Justice position is consistent with the unitary Executive Branch model which emphasizes that while there are many agencies in the Executive Branch, each is working for and reporting to the same president..$^{58}$

Nevertheless, there are several problems with this model of OMB as presidential agent, including the legal analysis that underpins it. In the first place, it is misleading to compare OMB involvement in rulemakings with other OMB activities: The uniqueness of the rulemaking process is recognized by the $\mathrm{APA}^{59}$ and the governing statutes for agencies. ${ }^{60}$ Second, it is gross understatement to label OMB's involvement "advisory" when the public record is replete with examples of OMB going far be-

Nixon analysis applies to presidential communications with an executive agency. See, e.g., Rosenberg, Beyond the Limits of Executive Power: Presidential Control of Agency Rulemaking Under Executive Order 12,291, 80 Mic:H. L. Rev. 193, 242 (1981) ("so long as the President remains free to thrash out alternatives secretly with his closest advisers, it is doubtful that disclosure would greatly impede his ability to recommend policies to executive agencies"). Second, Nixon held that what is and is not disclosable, given the presumption of confidentiality, is a highly contextual decision, and the Nixon Court found the constitutionally-based privilege not to exist in the context of a criminal trial. 418 U.S. at 713. $\Lambda$ court faced with a claim of executive privilege in a challenged OMB-influenced rulemaking might look for guidance, by way of analogy, to case law pertaining to the Freedom of Information Act Exemption 5, 5 U.S.C. $\S 552(b)(5)$ (1982) (exemption from disclosure for inter-agency or intraagency memoranda or letters that would not be available to party, other than agency, in litigation with agency). Under the analysis of NLRB v. Sears, Roebuck \& Co.. 421 U.S. 132 (1975), it may be that to the extent an agency wishes to rely on submissions by OMB as the basis for its decision, the agency could be forced to disclose such submissions. The agency might therefore be faced with the choice of disclosing (i.e., giving up privilege) or withdrawing the rule (i.e., giving up the policy).

In practice, a claim of executive privilege by an agency could be blunted by a procedure whereby the judge receives the affected documentation under seal. See, e.g., Environmental Defense Fund v. Thomas, No. 85-1747 (D.D.C. Nov. 18, 1985) (order requiring that various documents of OMB and EPA be released to plaintiff subject to certain conditions, and any confidential material must be kept under seal and available only to court and certain other persons).

57. See, e.g., United States v. Morgan, 313 U.S. 409, 422 (1941) (Secretary of Agriculture should never have been examined at trial concerning rate-making decision); National Nutritional Foods Ass'n v. FDA, 491 F.2d 1141, 1144-45 (2d Cir.) (strong showing of bad faith required before probing of mind allowed), cert. denied, 419 U.S. 874 (1974).

While the Morgan doctrine still constitutes a general prohibition, there has been some erosion in the doctrine. See, e.g., Citizens to Preserve Overton Park v. Volpe, 401 U.S. 402, 420 (1971) (court may require administrative officials to give testimony where there are no formal findings and examining decisionmakers may be only way to ensure effective judicial review).

58. This conception was explicitly recognized in Sierra Club v. Costle, 657 F.2d 298, 406 (D.C. Cir. 1981) (key executive policymakers cannot be isolated from each other and from Chief Executive). See also Strauss, The Place of Agencies in Government: Separation of Powers and the Fourth Branch, 84 Col.um. L. Rev. 573, 599 (1984) (President is to be unitary, politically accountable head of government).

59. See APA, 5 U.S.C. $§ 553$ (1982) (outlining rulemaking procedures); see also House Judiciary Comm. Report on the Administrative Procedure Act, H.R. ReP. No. 1980, 79th Cong., 2d Sess. 22 (1946), reprinted in Senate Comm. on Judiciary, 79th Cong., 2D Sess., Administrative ProCEDURE. ACr: LeGISLATIVE HISTORY at 256 (1946) (APA bill leaves each agency wide latitude to frame procedures) [hereinafter cited as APA LEGISLATIVE HiSTORY].

60. See, e.g., Strauss \& Sunstein, supra note 1, at 15-18 (distinguishing OMB role in development of budget from OMB role under E.O. 12,291, and noting that unlike statutory authority for coordination granted to President by Budget Act, it is agency head who enjoys authority under governing statutes). 
yond a mere advisory role. ${ }^{61}$ Third, it is not readily apparent that the deliberative process privilege extends to OMB involvement in agency rulemakings under E.O. 12,291. ${ }^{62}$ Finally, the need for a coordinating function suggested by the unitary view of the Executive Branch does not necessarily imply the scheme of direct supervision embodied in the E.O. 12,291 process. $^{\text {es }}$

\section{B. $O M B$ as Party to Rulemaking}

Under the model of OMB as Executive Branch party to an agency rulemaking, OMB would participate in an agency's rulemaking just as any other Executive Branch body would participate-i.e., as a party to the rulemaking. ${ }^{64}$ In an E.O. 12,291 rulemaking, Executive Branch departments and agencies may wish to express their views and are allowed to do so by submitting a statement for inclusion in the administrative record for that rulemaking. ${ }^{65}$

The main deficiency of this model is that in treating OMB like any other Executive Branch party, it ignores the unique leverage that OMB has over the rulemaking process under E.O. 12,291. ${ }^{\text {B }}$ Moreover, the model does not comport with the realities of E.O. 12,291 rulemakings: OMB involvement is generally not reflected in the administrative record and may therefore not be subject to judicial review. ${ }^{67}$ If the party model were applied to E.O. 12,291 rulemakings, OMB would either submit a

61. See supra text accompanying notes 8-10.

62. See supra note 56 .

63. See, e.g., Cutler \& Johnson, Regulation and the Political Process, 84 YALE L.J. 1395 (1975) (to extent functions of federal government have become more complex, with concomitant proliferation of federal agencies, it may be imperative for President to perform coordinating function). While OMB has become actively involved in directing the course of agency rulemaking under E.O. 12,291, a presidential coordination model requires that the President assume more of an advisory role focused particularly on resolving inter-agency disputes.

64. See, e.g., Morrison, Presidential Involvement in Informal Rulemaking: Striking the Proper Balance, 56 Tul. L. REv. 879, 886 (1982) (discussing approach whereby President, and his assistants, should be treated "just like everyone else" in recording and docketing written and oral communications).

65. In Public Citizen Health Research Group v. Rowland, Nos. 84-1252, 84-1392, and 85-1014 (D.C. Cir. filed March 4, 1985), see supra note 20, Executive Branch parties to the rulemaking included the Veterans $\Lambda$ dministration, the Department of Health and Human Services, the Department of the Army, EPA, and the Department of the Interior. See Joint Appendix to Brief-Volume II, at 552-62, Public Citizen Petitioners' Brief, supra note 20.

66. See supra note 52 (discussing powers of OMB). In Public Citizen, the Veterans Administration, for example, has no special leverage over OSHA; OMB, by contrast, does have leverage over OSH $\Lambda$ by virtue of its various powers. It is a mistake to ignore this leverage in considering OMB's role in the rulemaking process. For a catalogue of OMB's powers, see M. Rosenberg \& M. Gurevitz, Preliminary Catalogue of Office of Management and Budget Authoritics and Directives, Cong. Res. Serv. (Jan. 17, 1986) reprinted in OMB's Evolving Roles, supra note 6, at 395.

67. See supra notes 5,11 (discussing pattern of undocketed communications between agency and OMB). 
statement in writing for the administrative record or present testimony at the agency's public hearings.

\section{C. $O M B$ as Decisionmaking Authority}

The model of OMB as decisionmaking authority stresses the displacement of discretionary agency authority, a development which has been noted by commentators ${ }^{68}$ and recent litigants. ${ }^{69}$ The model draws attention to the fact that while formally the agency administrator must sign any rule submitted to the Federal Register, in reality OMB is responsible for the substance of that ultimate rule under E.O. 12,291. ${ }^{70}$

If $\mathrm{OMB}$ is considered the decisionmaker, then certain implications for judicial review follow. On the one hand, OMB might be protected by the general prohibition against probing the mind of the decisionmaker in the absence of bad faith. ${ }^{71}$ On the other hand, OMB, like any other agency undertaking a rulemaking, would be bound to provide a statement of reasons for its support of a particular rule. ${ }^{72}$ The central problem with this model is that it presumes $e x$ ante an extensive role for OMB as decisionmaker in a given rulemaking, an issue that the proposed expanded judicial review would in part be seeking to determine. ${ }^{73}$

\section{Hybrid Model: OMB as Party-Plus}

This Note advocates and adopts a hybrid model, OMB as party-plus, combining the second and third models above; this hybrid model represents the most accurate way to characterize OMB involvement. OMB is more than merely an advisor to agencies in E.O. 12,291 rulemakings, it has greater influence over these rulemakings than other Executive Branch parties, and yet it should not be presumed ex ante that OMB is the decisionmaker. Therefore, on the continuum of OMB influence over agency rulemaking, OMB has the status of a "party-plus."

68. See, e.g., Olson, supra note 1, at 43-46 (OMB exercises de facto veto power which displaces EPA discretion). Olson provides an excellent, in-depth study of OMB involvement in EPA rulemakings.

69. See, e.g., Public Citizen Petitioners' Brief, supra note 20, at 51 (arguing that Secretary of Labor ceded decisionmaking responsibility to $\mathrm{OMB}$ or had his authority taken away).

70. See, e.g., K. Davis, Administrative Law Treatise $\S 6: 40$, at 150 (Supp. 1982) (E.O. 12,291 does not technically transfer power from rulemaking agency to President, but in reality it does so due to threat of presidential power of removal).

71. See supra note 57.

72. See 5 U.S.C. $\$ 553(c)$ (1982) (requiring concise general statement of basis and purpose for rule).

73. Moreover, this model conflicts with the legislative history of the APA. See Senate Judiciary Comm. Print on the Administrative Procedure Act, 79th Cong., 1st Sess. 32 (1945), reprinted in APA LECist.A'Ttve. HistoRY, supra note 59, at 42 (Senate rejected centralized agency because "such an office. . . will be political, will interfere with the independent operations of boards and commissions, [and] will constitute a superadministrative agency"). 
If the courts embrace this hybrid characterization, they have a justification for demanding at a minimum that $\mathrm{OMB}$, like any other party, place its comments to the agency in the public record. ${ }^{74}$ In addition, since the party-plus characterization implies that OMB is in fact more than just another party to an E.O. 12,291 rulemaking, the courts have grounds for scrutinizing more closely OMB's participation in the rulemaking. ${ }^{75}$

\section{Beyond the Agency Record: Broadened Record Review of OMB-AgENCY CoMmunications}

Building on recognized exceptions to review on the record, this Note proposes broadened record review in the E.O. 12,291 context that will allow courts to examine OMB influence on rulemakings. The proposed approach makes use of "danger signals" analysis under which an alerted court would apply an analogue of the "hard look" doctrine.

\section{A. The Need for an OMB Exception to Review on the Record}

Despite the Supreme Court's establishment in Overton Park and $\mathrm{Camp}^{76}$ of a general prohibition against extra-record evidence, the lower courts have developed many exceptions to the Overton Park-Camp rule; these courts have considered evidence from outside the agency administrative record under a range of circumstances. ${ }^{77}$ One important exception involves cases where evidence considered by the agency has been left out of the formal record. ${ }^{78}$ The concern in these cases is that the agency can "skew the 'record' for review in its favor by excluding from that 'record' information in its own files which has great pertinence to the proceeding in question." "78 Another major exception to review on the record reaches

74. See supra text accompanying note 65 .

75. If $\mathrm{OMB}$ is considered the quasi-decisionmaker, then the court might apply almost the same degree of scrutiny to OMB's input to the E.O. 12,291 rulemaking process as it does where the agency is the exclusive decisionmaking authority. At a practical level, by taking a "hard look" at agency deliberations, courts will be able to scrutinize closely $\mathrm{OMB}$ input to agency decisionmaking. See infra text accompanying notes 91-94 (discussing hard look doctrine).

76. See supra text accompanying notes 13-15.

77. For an excellent discussion and overview of these exceptions, see Stark \& Wald, supra note 12 , at 343-54.

78. See, e.g., Sterling Drug Inc. v. FTC, 450 F.2d 698, 708 (D.C. Cir. 1971) ("to prevent the development of secret law within the Commission, we must require it to disclose orders and interpretations which it actually applies in cases before it"); National Courier Ass'n v. Board of Gov. of Fed. Reserve Sys., 516 F.2d 1229, 1241 (D.C. Cir. 1975) (courts should consider documents influencing agency decision to be evidence within statutory definition, subject only to claims of privilege); see also McMillan \& Peterson, supra note 12, at 342 n.54 (citing cases for the proposition that "if an agency were only required to produce the documents on which it relied (as opposed to all documents considered by agencyl, the agency might produce only those documents that support its position"); Stark \& Wald, supra note 12 , at 347-48 (discussing cases where factor considered by agency and not included in record).

79. See Environmental Defense Fund v. Blum, 458 F. Supp. 650, 661 (D.D.C. 1978). 
agency action that is not adequately explained. ${ }^{80}$ Where there is inadequate explanation, the lower courts, building on the Supreme Court's instructions for remand in Overton Park, have accepted new testimony or remanded the case to the agency for further explanation. ${ }^{\mathbf{}}$

Either or both of these exceptions may be implicated in the E.O. 12,291 context. The concern with agencies editing the record for review could arise in E.O. 12,291 rulemakings where an agency excludes information in its files related to its communications with OMB that might reveal the agency's original position in a rulemaking. ${ }^{82}$ The concern with inadequate explanation might arise where OMB involvement is not part of the public record, and the reviewing court may thus have no indication as to why the agency chose a final course of action that differed so sharply from its planned course of action. ${ }^{83}$

In view of the secrecy of OMB-agency communications and the significance of these communications for judicial review, the courts should develop a special OMB exception to review on the record. The courts should undertake broadened record review where there has been significant OMB involvement in a rulemaking. The trigger for this broadened record review should be a finetuned application of danger signals-type analysis.

\section{B. Triggering Broadened Record Review: Use of Danger Signals Analysis}

Where the courts find danger signals-evidence of abrupt shifts in agency policy-they take a closer look at agency rulemaking and require the agency to supply a reasoned analysis indicating why it is reversing previous policies and standards. ${ }^{84}$ The danger signals analysis has been applied recently in many deregulation cases, with the courts invalidating rescissions and suspensions of rules as "arbitrary and capricious."

80. See, e.g., County of Suffolk v. Secretary of Interior, 562 F.2d 1368, 1383-84 (2d Cir. 1977) (program option document prepared for Secretary contained information germane to decision and not duplicated elsewhere in record), cert. denied, 434 U.S. 1064 (1978). But see Madison County Bldg. \& Loan Ass'n v. Federal Home Loan Bank, 622 F.2d 393, 397 (8th Cir. 1980) (effective judicial review will not necessarily be frustrated without more detailed statement of reasons).

81. See Citizens to Preserve Overton Park v. Volpe, 401 U.S. 402,420 (1971). On remand, the district court held a twenty-five day trial, Overton Park, 335 F.Supp. 873, 878 (D. Tenn. 1972). See also Camp v. Pitts, 411 U.S. 138, 142-43 (1973) (where Comptroller's decision not sustainable on administrative record made, then decision must be vacated and matter remanded for further consideration); Stark \& Wald, supra note 12, at 345 (discussing remand technique used where further evidence may be necessary for reviewing court to make decision based on whole record).

82. See infra text accompanying notes 84-85 (discussing "danger signals").

83. See supra note 21 (discussing misleading agency rationalizations).

84. See Greater Boston Television Corp. v. FCC, 444 F. 2d 841, 852 (D.C. Cir. 1970) (agency may not gloss over or swerve from prior precedent without discussion if it is to avoid "cross[ingl the line from the tolerably terse to the intolerably mute"), cert. denied, 403 U.S. 923 (1971).

85. The "arbitrary and capricious" standard is one standard of review of agency action pursuant to 5 U.S.C. $\S 706(2)(\Lambda)(1982)$. For an application of this standard in deregulation cases, see, e.g., 
deregulation cases provide a useful analogy for OMB-influenced agency rulemakings. Given OMB involvement, "deregulation" may effectively take place in one step. ${ }^{86}$ Unlike deregulation that targets rules that have been in existence for years, OMB-influenced deregulation targets proposed rules within the period of the rulemaking process itself.

To trigger this broader record review, petitioner should have to establish preliminarily that there is strong reason to believe that the agency substantially altered its position as a result of OMB influence. Since $O M B$ can intervene in an agency rulemaking at several stages-from the birth of the idea of a regulation to the issuance of final rule itself ${ }^{87}$ - the court should respond to danger signals at whatever stage they appear in the particular rulemaking. ${ }^{88}$ Where the court finds the presence of danger signals, it should take the necessary steps to broaden the administrative record. ${ }^{89}$

\section{A Broadened Record to Enable a Judicial "Hard Look" at Rulemakings with Significant OMB Involvement}

While broadening the record may be the exception to the rule in most situations, in E.O. 12,291 rulemakings it is a virtual necessity to preserve meaningful judicial review. For judicial review to remain effective in policing the exercise of agency discretion, courts must go behind an agency rulemaking where there is OMB involvement. Whereas courts typically

Motor Vehicle Mfr's Ass'n v. State Farm Mut. Auto. Ins. Co., 463 U.S. 29, 40-57 (1983) (NHTSA's rescission of passive restraint requirement for automobiles was arbitrary and capricious); Center for Science in the Public Interest v. Department of the Treasury, 573 F. Supp. 1168, 1175-79 (D.D.C. 1983) (invalidating rescission of labeling regulations for alcoholic beverages), vacated as moot sub nom., Center for Science in the Public Interest v. Regan, 727 F.2d 1161 (D.C. Cir. 1984); see also Garland, supra note 21, at 525-26 (analyzing implementation of arbitrary and capricious standard through hard look approach in deregulation cases).

86. The sequence for E.O. 12,291 deregulation may be roughly outlined as follows: 1) proposal by agency for rule; 2) review by OMB for cost-benefit analysis; and 3) repeal of proposed rule by agency. Cf. Smythe, Judicial Reviezw of Rule Rescissions, 84 Colum. L. Rev. 1928, 1948 (1984) (describing sequence of events from birth to death of regulation under traditional deregulation model).

87. See ASBESTOS REPORT, supra note 5, at 118 ("the requirements of Executive Orders 12291 and 12498 may be properly viewed as an integrated process for presidential review and control of agency development of rules, from initial conception and formulation to final promulgation").

88. Such a flexible application of the danger signals analysis is necessary because OMB increasingly intervenes early in rulemakings under E.O. 12,291 (and also E.O. 12,498) in ways that may significantly alter or cut short the agency's intended course of action. Where there has been early $O M B$ intervention, potential plaintiffs will have difficulty challenging agency failure to act, because there will be no rulemaking record on which they can base their suit-a Catch 22 for potential plaintiffs. In these cases, courts might respond to less formal danger signals than where there had been a more fully developed rulemaking record. For example, courts under these circumstances could review such indicia of agency planning as press releases and public statements which might reflect a settled course of action prior to $\mathrm{OMB}$ involvement. For an illustration of how such danger signals might work, see ASBESTOS REPOR'1, supra note 5, at 12-13 (arguing that EPA had made four major policy statements in asbestos rulemaking proposing certain course of action, and had then abruptly reversed course as result of $\mathrm{OMB}$ pressure).

89. See infra note 98 and accompanying text. 
review the end result of agency rulemaking and the record support for the rule in accordance with the Morgan doctrine, courts must instead focus on the process of E.O. 12,291 rulemakings and the various interactions between the agency and OMB. ${ }^{80}$ This approach of penetrating an agency rulemaking is a prerequisite for compiling a complete record for judicial review.

Such an approach is consistent with the move by the courts in the last decade from a posture of deference to agency rulemaking towards the "hard look" doctrine.91 In general, the hard look doctrine, as it now stands, ${ }^{92}$ requires substantively that an agency's findings of fact have a basis in the record ${ }^{93}$ and that an agency's policy choice be reasonable. ${ }^{94}$ Where agency action does not survive hard look scrutiny, the judicial response has been invalidation of the rule for failure to pass the "arbitrary and capricious" test. ${ }^{95}$

In E.O. 12,291 rulemakings, courts will have difficulty enforcing the hard look doctrine if the administrative record does not reflect the crucial OMB involvement. ${ }^{96}$ Before courts can attempt to apply the hard look to

90. Normally, because of the Morgan prohibition against probing the mental processes of the decisionmaker, see supra note 57, courts do not engage in this kind of review. Nevertheless, precedent exists for courts trying "through an ad hoc effort to reconstruct what happened in a particular case." Pedersen calls this mode of compiling a record the "historical" approach as opposed to the "procedural" approach, where the record is compiled by the agency under a "given obligatory set of procedures." See Pedersen, Formal Records and Informal Rulemaking, 85 YALE L.J. 38, 62-64 (1975). Given the problems created for judicial review by undocumented OMB involvement in E.O. 12,291 rulemakings, courts should follow the "historical" approach since the courts will be required to ferret out what actually happened in the rulemaking. However, they can follow this approach in a carefully delimited manner-by seeking only that evidence which will shed light on OMB involvement. Thus, the courts will not be permitting "fishing expeditions."

91. See Garland, supra note 21, at 532-33 (comparing earlier narrow, more deferential scope of substantive review of agency decisionmaking under "minimum rationality" or "rational basis" test with emerging, two-pronged substantive hard look review).

92. See id. at 545-49 (discussing current two-pronged substantive approach to hard look). For a discussion of hard look doctrine earlier in its evolution, see S. BREYeR \& R. STEWART, ADMINISTRAtive Law AND Rrciulatrory Policy 292 (1979) (court reviews whether agency has adequately considered all relevant factors and considerations as well as made a reasoned choice). The principal difference between the earlier and current versions of the hard look doctrine centers on which party takes the hard look. Formerly, the purpose of the doctrine was to "ensure only that the agency had taken a hard look at the facts and issues before it, not that the court do so." Garland, supra note 21, at 533 (emphasis in original). Currently, the doctrine requires essentially that the court take a hard look at the agency's decision. Id.

93. In State Farm, the Court concluded, for example, that there was "no direct evidence in support of the agency's finding that detachable automatic belts cannot be predicted to yield a substantial increase in usage." Motor Vehicle Mfr's Ass'n v. State Farm Mut. Auto. Ins. Co., 463 U.S. 29, 52-53 (1983).

94. The State Farm Court "in effect concluded that, given the available alternatives, factual record, and congressional purpose, a reasonable administrator would not have made the choice" that the Department of Transportation did. Garland, supra note 21, at 548.

95. See supra note 85 .

96. See Olson, supra note 1 , at 77 (docketing is only way court can take "hard look" required to determine agency rationality). This Note agrees that the "hard look" is in jeopardy, but argues that docketing is an approach to disclosure that is best combined with this Note's proposal for broadened 
E.O. 12,291 rulemakings, they must ensure that the administrative record adequately reflects communications between the agency and OMB. ${ }^{97}$ Otherwise, the courts may be taking a hard look at a record that reveals little about what actually went into the agency decision. Only when a court is satisfied that it is reviewing the "whole record," including the various interactions between the agency and $\mathrm{OMB}$, will it be able to undertake the hard look analysis in a meaningful way.

A court can handle this process of broadening record review in roughly the same way it handles discovery requests. ${ }^{98}$ The broadened discovery can work in tandem with other approaches for disclosure such as congressionally-mandated disclosure ${ }^{9 \theta}$ and court-imposed logging requirements. ${ }^{100}$

record review. See infra note 100 and accompanying text.

97. At a practical level, the courts could ensure a complete record by following the Overton Park remand technique of accepting testimony of administrative officials or additional submissions where the documentary record submitted may not adequately disclose the nature of the agency-OMB interactions. See supra note 81 and accompanying text.

98. See, e.g., McMillan \& Peterson, supra note 12, at 347 (courts should insist on detailed affidavits regarding filing system used in rulemaking, scope of file search conducted, and personnel involved in search). Practical problems will inevitably arise if the courts of appeals end up supervising discovery. Nevertheless, in certain cases, where there are significant disputes between the parties, it may be necessary to appoint a master, see FED R. Civ. P. 53, or designate a district court judge to supervise discovery.

99. See, e.g., S. 2023, 99th Cong., 2d Sess., 132 Cong. Rec. S341 (daily ed. Jan. 27, 1986) (mandating establishment of agency rulemaking file detailing OMB involvement and role of outside parties in shaping that involvement). The bill has been sponsored by Senator Carl Levin (D-Mich.) and co-sponsored by Senator Dave Durenberger (R-Minn.) and Senator Warren Rudman (R-N.H.). For commentary on the bill, see Hearing on Oversight of OMB Regulatory Review Process, supra note 11 (statement of the author) (arguing that to extent disclosure requirements of bill work as intended, they could facilitate meaningful judicial review of OMB-influenced rulemakings).

OMB has recently instituted a new set of procedures related to E.O. 12,291 and E.O. 12,498. See Wendy L. Gramm, $\Lambda \mathrm{dm}$ 'r, Office of Information and Regulatory Affairs (OIRA), OMB, Memorandum for Heads of Departments and Agencies Subject to Executive Order Nos. 12291 and 12498, Subject: Additional Procedures Concerning OIRA Reviews Under Executive Order Nos. 12291 and 12498, June 13, 1986 (on file with the author). The OMB procedures contain too many loopholes to accomplish their ostensible purpose, i.e., increasing OMB accountability to the public. Specifically, the procedures do not require: (1) a summary of oral communications between agency and OMB officials on draft rules, (2) the disclosure of draft rules which are withdrawn by an agency following OMB review or returned for reconsideration following OMB review, and (3) the disclosure of correspondence between OIR $\Lambda$ and agency officials other than the agency head. In these critical respects, the OMB procedures are seriously flawed and far less satisfactory overall than the procedures proposed in S. 2023 .

100. See Olson, supra note 1 , at 76-77 (detailing what materials courts should require to be docketed). The Olson docketing proposal is sound because it reaches important comunications in an OMB-influenced rulemaking. Docketing will provide the courts with a point of entry for pursuing an approach based on this Note's proposal for broadened record review. If docketing is successful, it will furnish the courts with information that might enable them to undertake a more probing review of the dynamics of an OMB-influenced rulemaking. 


\section{Advantages of Broadened Record Review}

The proposed broadened record review represents an effort to deal with the problems created for judicial review by undocumented OMB involvement in the administrative process. It is designed to restore the effectiveness of judicial review in the face of the secret communications between OMB and the agency. By shoring up the judicial review mechanism, broadened record review will help preserve central public policy objectives in administrative law. Courts can ensure reasoned decisionmaking only by reviewing the actual record reflecting OMB-agency communications. Broadened record review will also enable courts to challenge with confidence any misleading rationalizations developed by the agency on the basis of the public record. Reviewing courts may find in the secret OMB record a basis for invalidating agency action as arbitrary and capricious. The prospect of such careful judicial scrutiny might in itself lead agencies to engage in reasoned decisionmaking on their own as they have in the past, independent of OMB influence.

Broadened record review will also safeguard public participation. The agency's public rulemaking record will serve as a counterpoint to the previously secret $\mathrm{OMB}$-agency communications. Broadened record review means that any improper OMB influence on agency rulemaking may come to light. To the extent improper influence is exposed by this broadened record review, public participation rights, which have assumed such significance in the last decade, may effectively be protected from the intrusions of OMB. Furthermore, where the secret OMB record is subject to judicial scrutiny, the public rulemaking record will again assume importance. The prospect of broadened record review might encourage agencies to return to the norm of public rulemaking proceedings.

\section{Conclusion}

The undocumented involvement of $\mathrm{OMB}$ in the administrative process poses a serious threat to the judicial review process. OMB involvement could cripple effective judicial review and therefore undermine important goals of administrative law, notably reasoned decisionmaking by agencies and access to the rulemaking process by all parties. To preserve meaningful judicial review, the courts must first reach the proper characterization of OMB involvement in agency rulemaking. With the characterization of $\mathrm{OMB}$ as a party-plus to rulemakings as a point of departure, the courts should undertake broadened record review of OMB-agency communications. The proposal for broadened record review builds on danger signals analysis, the hard look doctrine, and exceptions to review on the record. Broadened record review will reinvigorate the judicial review process in 
the OMB context and thus help preserve the integrity of the administrative process itself. 